\title{
Temporal variability of summer-time ozone and aerosols in the free troposphere over the eastern North Atlantic
}

\author{
J. M. Prospero ${ }^{1}$, R. Schmitt ${ }^{2}$, E. Cuevas ${ }^{3}$, D. L. Savoie ${ }^{1}$, W. C. Graustein ${ }^{4}$, \\ K. K. Turekian ${ }^{4}$, A. Volz-Thomas ${ }^{5}$, A. Díaz ${ }^{6}$, S. J. Oltmans ${ }^{7}$, H. Levy II $^{8}$
}

\begin{abstract}
In the free troposphere over Tenerife in the summer, $\mathrm{O}_{3}$ concentrations are anti-correlated with major pollutant aerosols (nss- $\mathrm{SO}_{4}^{-}$and $\mathrm{NO}_{3}^{-}$) and with ${ }^{210} \mathrm{~Pb}$, a tracer for boundary layer sources. In contrast, $\mathrm{O}_{3}$ is highly correlated with ${ }^{7} \mathrm{Be}$, a product of cosmic ray interactions in the upper troposphere and stratosphere. This suggests that natural $\mathrm{O}_{3}$ sources (i.e. the stratosphere) might be playing an important role. Nonetheless our results do not preclude the possibility that substantial amounts of pollution-related $\mathrm{O}_{3}$ could be transported in the free troposphere. However, to be consistent with our results, the transport mechanisms would have to incorporate efficient processes for the removal of pollutant aerosol species and ${ }^{21} \mathrm{~Pb}$.
\end{abstract}

\section{Introduction}

Tropospheric $\mathrm{O}_{3}$ is both a greenhouse gas and a strong oxidant and is a precursor to the formation of highly reactive radicals such as $\mathrm{OH}$ which play a critical role in controlling the lifetimes and fates of many chemical species [Levy, 1971; Thompson, 1992]. Tropospheric $\mathrm{O}_{3}$ is principally derived from two sources: episodic injection of air from the stratosphere where most of the Earth's $\mathrm{O}_{3}$ column inventory resides; and in situ photochemical production in the polluted continental boundary layer where most of the nitrogen oxides $\left(\mathrm{NO}_{\mathrm{x}}\right)$ and reactive organic carbon compounds (VOC's) are emitted. Conversely, there is the potential for net chemical destruction of $\mathrm{O}_{3}$ in the free troposphere where $\mathrm{NO}_{x}$ levels are low. Results from numerical simulations suggest that increasing anthropogenic emissions of both $\mathrm{NO}_{\mathrm{x}}$ and VOC's are leading to higher concentrations of tropospheric $\mathrm{O}_{3}$ throughout the northern hemisphere [e.g., Thompson, 1992]. Direct measurements indicate that $\mathrm{O}_{3}$ has been increasing at an annual rate of $1-2 \%$ per year for the past several decades at some relatively remote European surface sites and may have more than doubled over the last 100 years [Janach, 1989; Volz, 1993]. In contrast, a recent analysis of two decades of ozonesonde data from a wide range of sites [Logan, 1994] finds that, while $\mathrm{O}_{3}$ appears to have increased in the free

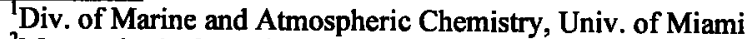

${ }^{2}$ Meteorologie Consult GmbH, Konigstein, Deutschland

${ }^{3}$ Inst. Nacional de Meteorología, Tenerife, Islas Canarias, España

${ }^{4}$ Dept. of Geology and Geophysics, Yale University

${ }^{5}$ Inst. Chemie Dynamik der Geosphäre, Jülich, Deutschland

'Universidad de La Laguna, Tenerife, Islas Canarias, España

${ }^{7}$ CMDL, NOAA, Boulder, Colorado

${ }^{8}$ GFDL, NOAA, Princeton, New Jersey
}

\section{Copyright 1995 by the American Geophysical Union.}

troposphere over a number of stations in Europe, it has remained relatively constant in most other regions [Oltmans, 1993; Logan, 1994], e.g. at Mauna Loa Observatory (MLO), Hawaii $\left(19.53^{\circ} \mathrm{N}, 155.57^{\circ} \mathrm{W}\right)$ [Oltmans and Levy, 1994].

The export of $\mathrm{O}_{3}$ from continental regions to the marine atmosphere involves complex meteorological [Moody et al., 1995] as well as chemical [Jacob et al., 1993] processes. This report focuses on data from Izaña, Tenerife, Canary Islands $\left(28^{\circ} 18 \mathrm{~N}, 16^{\circ} 29^{\prime} \mathrm{W}\right)$ where, as a part of the Tropospheric Ozone Research (TOR) program, $\mathrm{O}_{3}$ has been measured at a Spanish meteorological observatory located on a mountain ridge (elevation $2370 \mathrm{~m}$ ). This region is affected by a variety of air masses [Sancho et al., 1992], including relatively clean air from the central North Atlantic and more polluted air from Europe or North America. The data from Izafia are interesting because of the strong and coherent temporal changes in species concentration and their clear association with specific meteorological conditions.

Izaña experiences a pronounced orographic flow regime [Schmitt et al., 1988]. At night downslope winds prevail and samples should be representative of free tropospheric air. Night-time $\mathrm{O}_{3}$ at Izaña exhibits a marked seasonal cycle [Schmitt et al., 1988; Schmitt and Carretero, 1995]. From August through February, the composited monthly mean concentrations (1987-1994) are relatively constant, with values of 38-42 ppbv. Mean concentrations increase rapidly in the spring to a maximum of about $57 \mathrm{ppbv}$ in June and then decrease through the summer. The monthly means are similar to those at MLO [Oltmans and Levy, 1992] except from June through September when the Izaña means exceed those at MLO by $8-15$ ppbv.

The high summer means at Izafia have previously been attributed to the impact of anthropogenic species [Schmitt et al., 1988; Schmitt and Carretero, 1995]. Relatively high concentrations of $\mathrm{O}_{3}$ are generally associated with backtrajectories from north of Tenerife that pass over or close to Europe and North America. In some cases, by backtracking along trajectories, the $\mathrm{O}_{3}$ concentration measured at Izafia could be matched with good agreement to ozonesonde measurements over continental stations [Schmitt and Carretero, 1995]. Indeed, the Izaña monthly mean $\mathrm{O}_{3}$ concentrations are similar to those at non-urban sites in Europe throughout the year [Janach, 1989].

In this paper we use the concentrations of non-sea-salt (nss) $\mathrm{SO}_{4}^{-}, \mathrm{NO}_{3}^{-},{ }^{210} \mathrm{~Pb}$, and ${ }^{7} \mathrm{Be}$, to more thoroughly investigate the potential sources of the high summertime $\mathrm{O}_{3}$ concentrations at Izaña. Over the North Atlantic, $\mathrm{NO}_{3}^{-}$and nss- $\mathrm{SO}_{4}^{-}$are largely derived from anthropogenic sources [Savoie et al, 1992]. $\mathrm{Pb}-210\left(\tau_{1 / 2}=22\right.$ years $)$ is a decay product of ${ }^{222} \mathrm{Rn}\left(\tau_{1 / 2}=3.8\right.$ days) in soils; ${ }^{7} \mathrm{Be}\left(\tau_{1 / 2}=53\right.$ days $)$ is produced in the stratosphere and upper troposphere by cosmic ray interactions. Consequently these nuclides can serve as excellent tracers for the transport history of air parcels [Brost 
et al., 1991; Balkanski et al., 1993]. Although PAN (peroxyacetylnitrate), also measured at the site, can help in assessing the influence of anthropogenic sources, its concentrations during summer at Izaña are too low for this purpose, probably due to its dissociation at the typical summertime temperatures [Schmitt et al., 1988; Schmitt and Carretero, 1995; Schmitt, 1995].

\section{Results and Discussion}

Ozone is continuously monitored with a Dasibi UV absorption instrument whose calibration is tied to the U.S. National Institute of Standards and Technology reference $\mathrm{O}_{3}$ photometer maintained at Gaithersburg, Maryland [Oltmans and Levy, 1992]. Daily high-volume $\left(1 \mathrm{~m}^{3} \mathrm{~min}^{-1}\right)$ aerosol filter samples are collected at night (i.e., during downslope wind conditions) as a part of the Atmosphere/Ocean Chemistry Experiment (AEROCE). Samples for chemical analysis are collected on Whatman-41 filters and analyzed in Miami for nss- $\mathrm{SO}_{4}^{=}$(total aerosol $\mathrm{SO}_{4}^{-}$minus $\mathrm{Na}^{+}$times 0.2517 , the $\mathrm{SO}_{4}^{=} / \mathrm{Na}^{+}$ratio in bulk seawater) and $\mathrm{NO}_{3}^{-}$using ion chromatography [Savoie et al., 1992]. The radio-tracer samples are collected on quartz filters and analyzed at Yale using a high-purity germanium well gamma counter [Turekian et al., 1989].

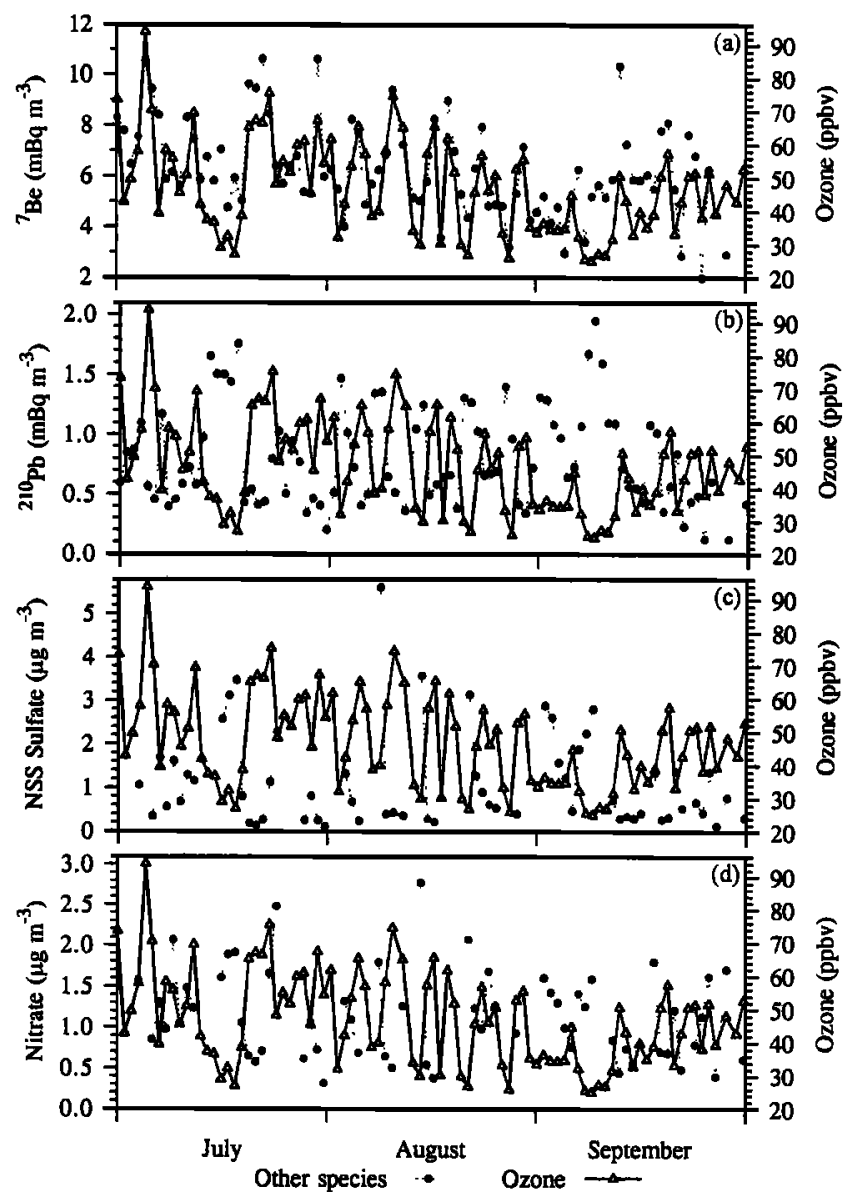

Figure 1. Daily mean night-time concentrations during JulySeptember 1991 of $\mathrm{O}_{3}$ with: (a) ${ }^{7} \mathrm{Be}$; (b) ${ }^{210} \mathrm{~Pb}$; (c) nss-SO $=$ and (d) $\mathrm{NO}_{3}^{-}$. Data joined by lines indicate contiguous samples.
Our filters quantitatively collect aerosol $\mathrm{NO}_{3}^{-}$and also gasphase $\mathrm{HNO}_{3}$, a major end-product of PAN decomposition. Thus our $\mathrm{NO}_{3}^{-}$measurements should yield a good estimate of the total of aerosol $\mathrm{NO}_{3}^{-}, \mathrm{HNO}_{3}$, and $\mathrm{PAN}$ that might have been present. At Izaña the $\mathrm{NO}_{3}^{-} / \mathrm{O}_{3}$ volume mixing ratio during high $\mathrm{O}_{3}$ events is typically in the range of 0.004 to 0.008 (i.e., $\mathrm{NO}_{3}^{-}$concentrations of $0.5-1 \mu \mathrm{g} \mathrm{m}^{-3}$ and $\mathrm{O}_{3}$ of 50 $60 \mathrm{ppbv}$ ). These ratios are in the range of values for the $\mathrm{NO}_{\mathrm{y}} / \mathrm{O}_{3}$ ratios measured in the upper troposphere over northern Europe [Murphy et al., 1993].

A daily time series of $\mathrm{O}_{3}$ and aerosol (night-time) data from July through September (henceforth, "summer") of 1991 shows that the day-to-day changes in $\mathrm{O}_{3}$ concentrations are strongly correlated with those of ${ }^{7} \mathrm{Be}$ (Fig. 1a). In every case, the maxima and minima in the $\mathrm{O}_{3}$ concentration data are associated with corresponding maxima and minima in ${ }^{7} \mathrm{Be}$. Note the series of sharp one-day changes around mid-July and just after mid-August. In contrast, the $\mathrm{O}_{3}$ time series is strongly anticorrelated with that of ${ }^{210} \mathrm{~Pb}$ (Fig. 1b). Often ${ }^{210} \mathrm{~Pb}$ changes by a factor of two or more in a one-day period while $\mathrm{O}_{3}$ undergoes an equally sharp opposite change. There are also extended periods of low $\mathrm{O}_{3}$ that are accompanied by high concentrations of ${ }^{210} \mathrm{~Pb}$ (e.g., 6 days in mid-July and 12 days in early September).

Lower nss- $\mathrm{SO}_{4}^{=}$and $\mathrm{NO}_{3}^{-}$concentrations (Fig. 1c and 1d, respectively) are almost invariably associated with peaks in $\mathrm{O}_{3}$; conversely aerosol maxima coincide with $\mathrm{O}_{3}$ minima. The temporal changes in nss- $\mathrm{SO}_{4}^{=}$are particularly remarkable. Many of the nss- $\mathrm{SO}_{4}^{-}$values that are associated with the $\mathrm{O}_{3}$ peaks are in the range of $0.1-0.4 \mu \mathrm{g} \mathrm{m}^{-3}$ (23-93 pptv), comparable to those at remote South Pacific sites [Savoie et al., 1989]. In contrast, the peak concentrations of nss- $\mathrm{SO}_{4}^{=}$ (usually associated with low $\mathrm{O}_{3}$ values) are often a factor of ten or more higher. The $\mathrm{NO}_{3}^{-}$data (Fig. 1d) show a pattern that is similar to that for nss- $\mathrm{SO}_{4}^{=}$. Samples having high concentrations of nss- $\mathrm{SO}_{4}^{-}, \mathrm{NO}_{3}^{-}$, and ${ }^{210} \mathrm{~Pb}$ usually contained high concentrations of mineral dust as reflected in the aluminum concentrations (e.g. Fig. 2c; Arimoto et al., 1995); these filters also had a very pronounced red-brown coloration that is characteristic of Saharan dust [Prospero and Nees, 1986]. Dust from large-scale dust storms, which occur often during the summer months in North Africa, is transported across the west coast of Africa, typically reaching altitudes of 6-8 $\mathrm{km}$ and covering large areas of the tropical North Atlantic [Carlson and Prospero, 1972; Prospero and Nees, 1986].

A series of scatterplots shows that the relationships in the summer of 1991 discussed above are generally valid for the entire data set from Izana. In these plots, the data are partitioned into two groups, those for which $\mathrm{O}_{3}$ concentrations are greater than $50 \mathrm{ppbv}$ ("high $\mathrm{O}_{3}$ ") and those for concentrations less than $35 \mathrm{ppbv}$ ("low $\mathrm{O}_{3}{ }^{\prime \prime}$ ). The scatterplot of ${ }^{210} \mathrm{~Pb}$ versus ${ }^{7} \mathrm{Be}$ (Fig. 2a) shows that high $\mathrm{O}_{3}$ is associated with high ${ }^{7} \mathrm{Be}$ and low ${ }^{210} \mathrm{~Pb}$ and, conversely, that low $\mathrm{O}_{3}$ is associated high ${ }^{210} \mathrm{~Pb}$ and low ${ }^{7} \mathrm{Be}$. A scatterplot of nss- $\mathrm{SO}_{4}^{=}$versus ${ }^{210} \mathrm{~Pb}$ (Fig. 2b) shows that nss- $\mathrm{SO}_{4}^{=}$is well correlated with ${ }^{210} \mathrm{~Pb}$. Within this distribution, the low $\mathrm{O}_{3}$ values are tightly clustered at the high end of the nss- $\mathrm{SO}_{4}^{=} / 210 \mathrm{~Pb}$ distribution whereas the high $\mathrm{O}_{3}$ values are clustered at the low end.

As previously stated, high concentrations of nss- $\mathrm{SO}_{4}^{\overline{-}}$ and $\mathrm{NO}_{3}^{-}$are usually associated with high concentrations of aluminum from mineral dust. Figure $2 \mathrm{c}$ shows that $\mathrm{nss}-\mathrm{SO}_{4}^{=}$ concentrations above about $1 \mu \mathrm{g} \mathrm{m}^{-3}$ are usually associated 

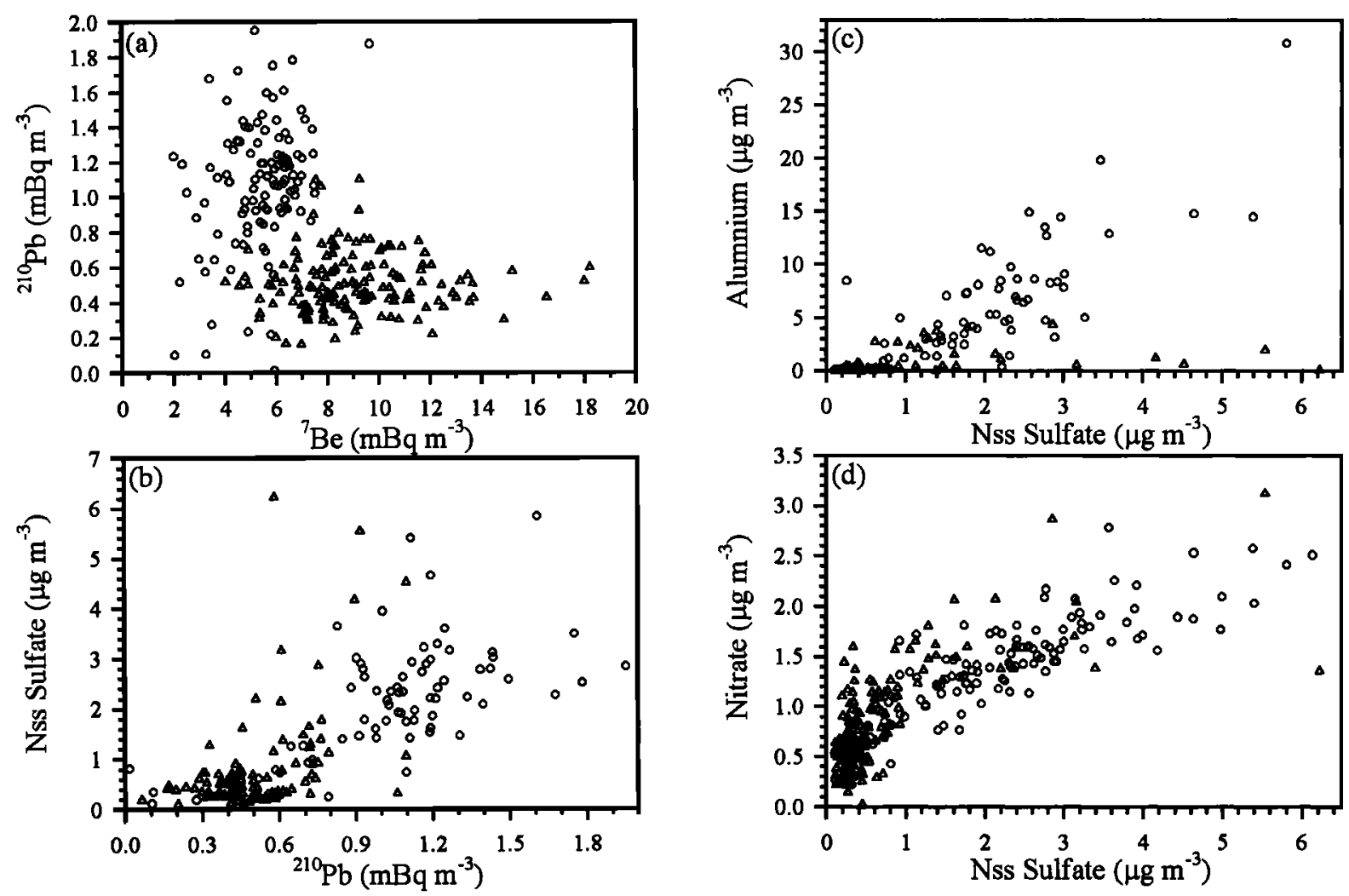

Figure 2. Scatterplot of July-September night-time aerosol concentrations at Izaña. Data are selected and partitioned for $\mathrm{O}_{3}$ concentrations greater than $50 \mathrm{ppbv}(\Delta)$ and less than $35 \mathrm{ppbv}(\mathrm{O})$. (a) ${ }^{210} \mathrm{~Pb}$ vs. ${ }^{7} \mathrm{Be}, 1$ July $1989-31$ August 1993; (b) nss-SO vs. ${ }^{10} \mathrm{~Pb}, 1$ July 1989-31 August 1993; (c) aluminum vs. nss-SO ${ }_{4}^{-}, 2$ July 1989-30 September 1992; and (d) $\mathrm{NO}_{3}^{-}$vs. nss-SO 25 July 1987-30 September 1994.

with $\mathrm{Al}$ concentrations of several $\mu \mathrm{g} \mathrm{m}^{-3}$ or greater (i.e., dust concentrations of $10^{\prime} \mathrm{s}$ of $\mu \mathrm{g} \mathrm{m}^{-3}$ or more). These samples are generally characterized by low $\mathrm{O}_{3}$ concentrations. Conversely, the high $\mathrm{O}_{3}$ group is primarily associated with extremely low $\mathrm{Al}$ concentrations and with nss-SO concentrations less than $1 \mu \mathrm{g} \mathrm{m}^{-3}$.

Although the time sequence of high-low aerosol $\mathrm{NO}_{3}^{-}$ concentrations (Fig. 1d) is similar to that for nss- $\mathrm{SO}_{4}^{\overline{-}}$ (Fig. $1 \mathrm{c}$ ), it differs in one major respect. The low $\mathrm{NO}_{3}^{-}$values (associated with $\mathrm{O}_{3}$ peaks) are typically between 0.5 to 1 $\mu \mathrm{g} \mathrm{m}^{-3}$ (180-360 pptv). These values are 5 to 10 times higher than South Pacific values [Savoie et al., 1989] where anthropogenic impacts are minimal. At Izafía the mass ratio of $\mathrm{NO}_{3}^{-}$to nss- $-\mathrm{SO}_{4}^{-}$changes markedly with respect to the $\mathrm{O}_{3}$ concentration changes. Figure $2 \mathrm{~d}$ shows the entire JulySeptember Izaña data set for 1987-1994 partitioned according to $\mathrm{O}_{3}$ concentration. When aerosol concentrations are high (e.g., above about $1 \mu \mathrm{g} \mathrm{m}^{-3}$ ), the $\mathrm{NO}_{3}^{-} / \mathrm{nss}^{-\mathrm{SO}_{4}^{-}}$mass ratio falls between 0.5 to 1 , values that are typical for polluted air masses; these conditions are usually associated with low $\mathrm{O}_{3}$. When aerosol concentrations are low (less than about 1 $\left.\mu \mathrm{g} \mathrm{m}^{-3}\right)$, the $\mathrm{NO}_{3}^{-} / \mathrm{nss}^{-} \mathrm{SO}_{4}^{-}$mass ratio is usually much greater than 1, values that are high compared to typical pollution aerosols; these occasions usually coincide with relatively high $\mathrm{O}_{3}$ values (in Fig. 2d, over 50 ppbv).

Because of the similarities between the temporal variability of ${ }^{210} \mathrm{~Pb}$ and that of nss- $\mathrm{SO}_{4}^{-}$and $\mathrm{NO}_{3}^{-}$and because of the high concentrations of nss- $\mathrm{SO}_{4}^{-}$and $\mathrm{NO}_{3}^{-}$during periods of high ${ }^{210} \mathrm{~Pb}$, we conclude that the nss- $\mathrm{SO}_{4}^{-}$and $\mathrm{NO}_{3}^{-}$are transported from continental pollution sources. This interpretation is supported by isentropic trajectories [J. Merrill, personal communication; see Moody et al., 1995] which, on days when the concentration of nss- $\mathrm{SO}_{4}^{-}$and $\mathrm{NO}_{3}^{-}$are high, usually track back across North Africa, often hooking north to Europe. These trajectories are consistent with the fact that these samples usually contain very high concentrations of mineral dust as previously discussed. In contrast, the high $\mathrm{O}_{3}$ (and low aerosol) events were generally associated with trajectories that came from the north in the middle and upper troposphere but which generally do not pass over continental Europe. The tight clustering of high- $\mathrm{O}_{3}$ events at the low end of the $\mathrm{Al}$ versus nss-SO $=$ with this interpretation. Our trajectory results are consistent with the Izaña trajectory climatology [Sancho et al., 1992] which shows that, during July-September, $700 \mathrm{mb}$ trajectories (the pressure altitude applicable to Izaña) fall largely into two classes: one group (26-37\% of the cases by month) comes from over the North Atlantic (and possibly North America) north of $28^{\circ} \mathrm{N}$ (the latitude of Izana); a second group (23$35 \%$ ) passes over North Africa (and possibly Europe). At $700 \mathrm{mb}$, only a very small percentage of the trajectories (2$3 \%$ ) come directly from Europe or England.

\section{Conclusions}

During the summer, high $\mathrm{O}_{3}$ events at Izaña are associated with air masses that contain very low concentrations of aerosol species that are usually characteristic of "polluted" air masses. Conversely, samples that had high concentrations of pollution aerosols were usually associated with relatively low concentrations of $\mathrm{O}_{3}$ and with trajectories that had passed over North Africa (and, usually, Europe). If one assumes that 
these polluted air masses initially contained high concentrations of $\mathrm{O}_{3}$, then much of the $\mathrm{O}_{3}$ must have been subsequently destroyed in transit. The net balance of $\mathrm{O}_{3}$ production and destruction depends critically on the concentration of $\mathrm{NO}_{x}$ and the concentration of water vapor. Our data suggest that for the cases with high aerosol concentrations, losses of $\mathrm{O}_{3}$ appear to dominate over production on the time scales that it takes to transport air from pollution sources in Africa and Europe (i.e., a few days). The African-European trajectories generally lie at higher altitudes (e.g., $700 \mathrm{mb}$ [Sancho et al., 1992]) and the air is extremely dry [Carlson and Prospero, 1972] so that the water-vaporrelated destruction processes for $\mathrm{O}_{3}$ should be relatively inefficient. The large surface area available on dust might be a factor in the $\mathrm{O}_{3}$ loss.

While our data can be interpreted to imply a substantial impact from upper tropospheric (and, perhaps, stratospheric) $\mathrm{O}_{3}$ sources, they do not preclude the possibility that significant amounts of $\mathrm{O}_{3}$ might be photochemically produced in the free troposphere or transported there from surface sources via convective clouds [Pickering et al., 1992]. If boundary layer sources are playing an important role in freetroposphere $\mathrm{O}_{3}$, then the transport mechanism from the boundary layer must efficiently remove pollutant $\mathrm{nss}^{-\mathrm{SO}_{4}}=$ $\mathrm{NO}_{3}^{-}$aerosols and their gaseous precursors, especially $\mathrm{SO}_{2}$ along with the tracer ${ }^{210} \mathrm{~Pb}$. In contrast, $\mathrm{O}_{3}, \mathrm{NO}_{\mathrm{x}}, \mathrm{PAN}$, organic nitrates, and VOC's, being relatively insoluble, would be vented to the free troposphere where subsequent chemistry could slowly produce $\mathrm{O}_{3}$ [e.g., Liu et al., 1987] and oxidize the remaining $\mathrm{NO}_{\mathrm{x}}$ to $\mathrm{NO}_{3}^{-}$. As the destruction rates of $\mathrm{O}_{3}$ are also slow in the free troposphere (because of the low water vapor content) the net effect of the production and destruction processes could be to maintain relatively high levels of surface-derived $\mathrm{O}_{3}$ along with high $\mathrm{NO}_{3}^{-}$values. The removal of ${ }^{210} \mathrm{~Pb}$, would obscure the signature for the surface origin of the air parcel [Balkanski et al., 1993].

Acknowledgments. We thank the Spanish Meteorological Service (INM) for their cooperation in this program, especially C. Rus. We are particularly grateful to the Izaña Observatory staff who carried out many of the routine operations. This work is supported by National Science Foundation grants ATM-8703411, ATM9013125, ATM-9414808, ATM-8701292, and ATM-9012950 and the National Atmospheric and Oceanic Administration, Dept. of Commerce. TOR activities are supported by the German Ministry of Research and Technology (BMFT) under grant 07EU7649/A.

The editor thanks the referees for their assistance in evaluating this paper.

\section{References}

Arimoto, R., R. A. Duce, B. J. Ray, W. G. Ellis, Jr., J. D. Cullen, and J. T. Merrill, Trace elements in the atmosphere over the North Atlantic, J. Geophys. Res., 100, 1199-1213, 1995.

Balkanski, Y. J., D. J. Jacob, G. M. Gardner, W. C. Graustein, and K. K. Turekian, Transport and residence times of tropospheric aerosols inferred from a global three-dimensional simulation of ${ }^{210} \mathrm{~Pb}$, J. Geophys. Res., 98, 20,573-20,586, 1993.

Brost, R. A., J. Feichter, and M. Heimann, Three-dimensional simulation of ${ }^{7} \mathrm{Be}$ in a global climate model, J. Geophys. Res., 96, 22,423-22,445, 1991.

Carlson, T. N., and J. M. Prospero, The large-scale movement of Saharan air outbreaks over the northern equatorial Atlantic, $J$. Appl. Meteorol., 11, 283-297, 1972.

Jacob, D.J., J.A. Logan, G.M. Gardner, R.M. Yevich, C.M. Spivakovsky, S.C. Wofsy, S. Sillman, and M.J. Prather, Factors regulating ozone over the United States and its export to the global atmosphere, J. Geophys. Res., 98, 14,817-14,826, 1993.

Janach, W. E., Surface ozone: trend details, seasonal variations, and interpretation, J. Geophys. Res., 94, 18,289-18,295, 1989.

Levy, H., II, Normal atmosphere: large radical and formaldehyde concentrations predicted, Science, 173, 141-143, 1971.

Liu, S. C., M. Trainer, F. C. Fehsenfeld, D. D. Parrish, E. J.
Williams, D. W. Fahey, G. Hübler, and P. C. Murphy, Ozone production in the rural troposphere and the implications for regional and global ozone distributions, J. Geophys. Res., 92, 4191-4207, 1987.

Logan, J. A., Trends in the vertical distribution of ozone: An analysis of ozonesonde data, J. Geophys. Res., 99, 25,55325,586, 1994.

Moody, J. L., S. J. Oltmans, H. Levy II, and J. T. Merrill, Transport climatology of tropospheric ozone: Bermuda, 1988-1991, $J$. Geophys. Res., 100, 7179-7194, 1995.

Murphy, D. M., D. W. Fahey, M. H. Proffitt, S. C. Liu, K. R. Chan, C. S. Eubank, S. R. Kawa, and K. K. Kelly, Reactive nitrogen and its correlation with ozone in the lower stratosphere and upper troposphere, J. Geophys. Res., 98, 8751-8773, 1993.

Oltmans, S. J., Climatology of Arctic and Antarctic ozone, in The Tropospheric Chemistry of Ozone in the Polar Regions, edited by H. Niki, pp. 25-40, Springer, Berlin. 1993.

Oltmans, S. J., and H. Levy, II, Seasonal cycle of surface ozone over the western North Atlantic, Nature, 358, 392-394, 1992.

Oltmans. S. J., and H. Levy, II, Surface ozone measurements from a global network, Atmos. Environ., 28, 9-24, 1994.

Pickering, K. E., A. M. Thompson, J. R. Scala, W.-K. Tao, R. R. Dickerson, and J. Simpson, Free tropospheric ozone production following entrainment of urban plumes into deep convection, $J$. Geophys. Res., 97, 17,985-18,000, 1992.

Prospero, J. M., and R. T. Nees, Impact of the North African drought and El Niño on mineral dust in the Barbados trade wind, Nature, 320, 735-738, 1986.

Sancho, P., J. de la Cruz, A. Díaz, F. Martín, E. Hernández, F. Valero, and B. Albarrán, A five-year climatology of backtrajectories from the Izaña baseline station, Tenerife, Canary Islands, Atmos. Environ., 26A, 1081-1096, 1992.

Savoie, D. L., J. M. Prospero, J. T. Merrill, and M. Uematsu, Nitrate in the atmospheric boundary layer of the tropical South Pacific: Implications regarding sources and transport, J. Atmos. Chem., 8, 391-415, 1989.

Savoie, D. L., J. M. Prospero, S. J. Oltmans, W. C. Graustein, K. K. Turekian, J. T. Merrill, and H. Levy II, Sources of nitrate and ozone in the marine boundary layer of the tropical North Atlantic, J. Geophys. Res., 97, 11,575-11,589, 1992.

Schmitt, R., B. Schreiber, and I. Levin, Effects of long-range transport on atmospheric trace constituents at the Baseline Station Tenerife (Canary Islands), J. Atmos. Chem., 7, 335-351, 1988.

Schmitt, R., and M. Carretero, Ozone in the free troposphere over the North Atlantic: Production and long range transport, in Proceedings of EUROTRAC Symposium, 1995 (in press).

Thompson, A. M., The oxidizing capacity of the earth's atmosphere: probable past and future changes, Science, 256, 1157-1165, 1992.

Turekian, K. K., W. C. Graustein, and J. K. Cochran, Lead-210 in the SEAREX program: An aerosol tracer across the Pacific, in Chemical Oceanography, vol. 10, edited by J. P. Riley, R. Chester, and R. A. Duce, pp. 51-81, Academic, San Diego, Calif., 1989.

Volz, A., Trends in photo-oxidant concentrations, in Proceedings of EUROTRAC Symposium '92, edited by P.M. Burrell et al., pp. 5964, Academic Pub., The Hague, 1993.

E. Cuevas, Instituto Nacional de Meteorología, Tenerife, Islas Canarias, España (e-mail: ecuevas@ull.es)

A. Díaz, Universidad de La Laguna, Tenerife, Islas Canarias, España (e-mail: adiaz@ull.es)

W. C. Graustein and K. K. Turekian, Department of Geology and Geophysics, Yale University, New Haven, CT (e-mail: billg@lamb.geology.yale.edu; kkt@milne.geology.yale.edu)

H. Levy II, Geophysical Fluid Dynamics Laboratory, National Oceanic and Atmospheric Administration, Princeton, NJ (e-mail: hl@gfdl.gov)

S. J. Oltmans, Climate Monitoring and Diagnostics Laboratory, National Oceanic and Atmospheric Administration, Boulder, CO (e-mail: soltmans@cmdl.noaa.gov)

J. M. Prospero and D. L. Savoie, Division of Marine and Atmospheric Chemistry, University of Miami, Miami, FL 33149 (e-mail: jprospero@rsmas.miami.edu; dsavoie@rsmas.miami.edu)

R. Schmitt, Meteorologie Consult GmbH, Konigstein, Deutschland (e-mail: 100060.2416@CompuServe.com)

A. Volz-Thomas, Inst. Chemie Dynamik der Geosphäre, Jülich, Deutschland (e-mail: a.volz-thomas@kfa-juelich.de)

(Received March 28, 1995; revised July 18, 1995; accepted September 5, 1995) 